\title{
An Electrochemical DNA Sensor for p53 Tumor Suppressor Gene Detection
}

\author{
Jie Zhang ${ }^{1}$, Long Wan ${ }^{2}$, Hao Fan ${ }^{1}$, Fusheng Liao ${ }^{1}$ \\ ${ }^{1}$ Department of Pharmacy, JiangXi University of Traditional Chinese Medicine, JiangXi 330004, China \\ ${ }^{2}$ NanChang Teachers College, JiangXi 330004, China
}

\begin{abstract}
In this work, a sensitive electrochemical DNA sensor based on avidin modified electrode and DNA-functionalized Cds nanoparticle (DFNP) was developed. The DNA-Functionalized Cds nanoparticle contained two kinds of DNA, one was hairpin probe DNA with a biotin at the 3 ' terminal and a thiol at the 5' terminal, the other is linearity signal DNA. Without hybridized with target DNA, the loop of hairpin impeded biotin linked with avidin on electrode. However, after target hybridization, hairpin was opened and biotin was recognized by avidin resulting in DNA-functionalized Cds nanoparticle was brought on electrode surface. Electrochemical signals of methylene blue (MB) bound to the signal DNA were measured by differential pulse voltammetry (DPV). Introduction By using this new method, we demonstrate that this prototype sensor has been able to detect as low as picomolar p53 tumor suppressor gene with excellent differentiation ability for even single mismatches.
\end{abstract}

\section{Introduction}

The p53 tumor suppressor gene, well known as a transcription factor of cell regulation, is the most commonly mutated gene in human tumors. About $50 \%$ of all malignancies contain a mutation in $\mathrm{p} 53$ and aggressive growth of several types of cancer has been attributed to mutations in this gene. Moreover, p53, as the "master switch" for the control of cell proliferation, plays an important role in inducing cell cycle arrest for DNA repair or apoptosis to eliminate severely damaged cells. Sequence-specific analysis of the p53 gene could help early diagnosis of cancer development and consequently increase the success of the treatment Therefore, sensitive and rapid detection of p53 gene and the mutations in the p53 gene are of great value. [1-6]

The electrochemical DNA sensing technology has received particular attention mostly due to its high sensitivity, selectivity and easy operation with simple instrumentations. [7-10] The DNA recognition event can be detected using different strategies, including intrinsic electroactivity of the nucleic acid, enzyme labels, DNA duplex intercalators, electroactive markers, and metal nanoparticles/quantum dots.

We herein reported a non-immobilizing electrochemical DNA sensor with hybridization occurred in one homogeneous solution that employed DNA-functionalized Cds nanoparticle (DFNP) and avidin modified electrode. In the present study, we have developed a DNA-functionalized Cds nanoparticle, integrated DNA recognition; signal amplification and specific biotin- avdin link functional section, as probe for
DNA detection and featured high sensitivity up to low pmtomolar. In target DNA detection, as Figure 1, when the probe DNA of DFNP is under stem-loop state, comparatively huge bulk of $\mathrm{Cds}$ nanoparticle and the loop of probe DNA would prevent biotin on the probe DNA be captured by the avidin on the electrode for the spatial effects. After the DFNP solution is incubated in a buffer solution containing target DNA, target DNA would combine probe DNA by forming double strand with complementary sequences, which ccdssed hairpin open and eliminate steric hindrance to biotin. Afterwards, when avidin modified electrode was immersed in a solution after the hybridization event happened, the biotin of the DFNP could have attached to avidin on the electrode and thus was captured on the electrode. The electrochemical signals of MB of signal DNA were measured by differential pulse voltammetry (DPV). Taking advantage of amplification effects of the Cds nanoparticle (CdsNP) and binding specificity of hairpin probe, this biosensor greatly simplifies the electrochemical detection method of DNA and displays higher specificity than the linear probe in DNA detection.

\section{Experiment section}

\subsection{Apparatus}

All voltammetric experiments were performed using a $\mathrm{CHI}$ 660 electrochemical analyzer (CHI Instrument Inc, USA). Electrochemical experiments were carried out in a $3 \mathrm{ml}$ electrochemical cell at room temperature $\left(25^{\circ} \mathrm{C}\right)$ by using three electrode configurations. A platinum wire served as a 
counter electrode and an $\mathrm{Ag} / \mathrm{AgCl}$ as reference electrode with saturated $\mathrm{KCl}$ solution.

Unless otherwise noted, all chemicals were purchased from Dingguo Biotechnology Inc. (Shanghai, China) and of analytical reagent grade. The biotin and avidin were pur chased from Sangon Biotechology Inc. (Shanghai, China). All of the solutions were prepared with ultrapure water from a Millipore Milli-Q system.

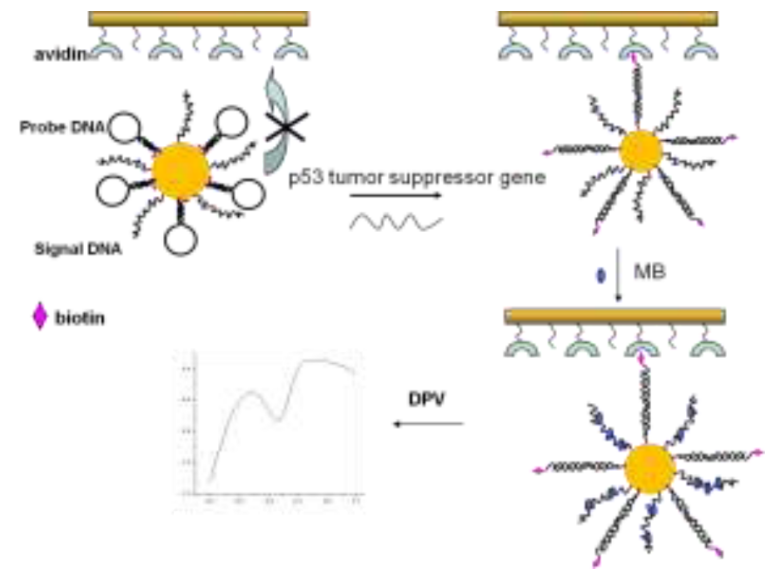

Figure 1. Scheme for the DNA-functionalized Cds nanoparticle-based electrochemical DNA sensor.

\subsection{Materials}

All the probes and target oligonucleotides were purchased from Takara Biotechnology Company. The oligonucleotides were purified via $\mathrm{C} 18$ reversed-phase HPLC and polyacrylamide gel electrophoresis (PAGE). The stem-loop probe oligonucleotide (oligo 1) has a $5^{\prime}$-HS label and a 3'-biotin, which will form the stem at appropriate ionic strength. The MB-labeled signal DNA (oligo 2). The sequence of the target (oligo 3) is perfectly matched to the loop sequence of the probe; oligo 4 contains a one-base mismatch, while oligo 5 has three-base mismatches. Oligo 6 is a random sequence unrelated to the probe sequence. Unless otherwise noted, all chemicals were purchased from Dingguo Biotechnology Inc. (Shanghai, China) and of analytical reagent grade. The biotin and avidin were pur chased from Sangon Biotechology Inc. (Shanghai, China). All of the solutions were prepared with ultrapure water from a Millipore Milli-Q system.

\subsection{Preparation of nano CdS}

$\mathrm{Cd}\left(\mathrm{NO}_{3}\right)_{2}$ and $\mathrm{Na}_{2} \mathrm{~S}$ solutions were filtered through a $22 \mathrm{~m}$ microporous membrane filter prior to use. CdS nanoparticles were prepared by using mercaptoacetic acid as the stabilizer. In brief, $9.22 \mu \mathrm{l}$ mercaptoacetic acid was added to $50 \mathrm{ml} 0.4 \mathrm{mM} \mathrm{Cd}\left(\mathrm{NO}_{3}\right)_{2}$ solution, and then the $\mathrm{pH}$ was adjusted to 7 with $0.5 \mathrm{M} \mathrm{NaOH}$. The solution was bubbled with nitrogen for $30 \mathrm{~min}$, followed by the slow addition of $1.34 \mathrm{mM} \mathrm{Na} 2 \mathrm{~S}$ to the mixture solution. The molar ratio of $\mathrm{Na} 2 \mathrm{~S}$ to $\mathrm{Cd}\left(\mathrm{NO}_{3}\right)_{2}$ was kept at 2.5. The reaction was carried out for $24 \mathrm{~h}$ under nitro-gen protection and then gradually a brown colloid which is the $\mathrm{CdS}$ nanoparticles covered with a carboxyl group was obtained.
As TEM images show, the diameter of CdS nanopatricles was about $7 \mathrm{~nm}$.

\subsection{Preparation of the DNA-functionalized Cds nanoparticles}

The process of probe DNA and signal DNA labeling was performed according to paper as follows: The mixture of $5.6 \mathrm{nM}$ probe DNA and $2.8 \mathrm{nM}$ signal DNA was activated with acetate buffer ( $\mathrm{pH} 5.2)$ and $1.5 \mu \mathrm{L}$ of $10 \mathrm{mM}$ TCEP for $1 \mathrm{~h}$, then added to $1 \mathrm{~mL}$ of freshly prepared $\mathrm{Cds}$ nanoparticles, and shaken gently overnight. Over the course of $16 \mathrm{~h}$, the DNA-CdsNP conjugates were aged in salts $(0.1 \mathrm{M} \mathrm{NaCl}, 10 \mathrm{mM}$ acetate buffer$)$ for another $24 \mathrm{~h}$. Excess reagents were removed by centrifuging at 16000 rpm for $30 \mathrm{~min}$. The red precipitate was washed and centrifuged repeatly for three times. The resulting nanoparticles were dispersed into a buffer solution $(0.1 \mathrm{M}$, containing $0.3 \mathrm{M} \mathrm{NaCl}$ and $2 \mathrm{mM} \mathrm{Mg}^{2+}, \mathrm{pH} 8.1$ ) and stored at $4{ }^{\circ} \mathrm{C}$.

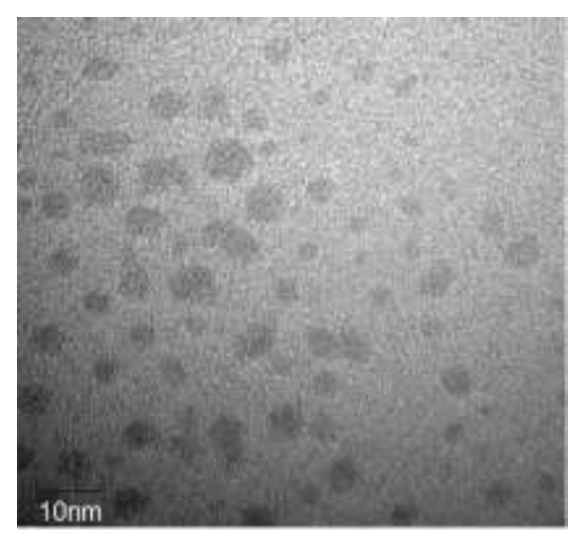

Figure 2. TEM image of the synthesized CdS nanoparticles.

\subsection{Preparation of avidin-coated electrode surfaces}

The gold electrode was exposed to an ethanolic $5 \mathrm{mM}$ solution of 3,3'-dithiodipropionic acid for $30 \mathrm{~min}$, followed by water rinsing. $5 \mu \mathrm{l}$ of $100 \mathrm{mg} \mathrm{mL}-1 \mathrm{EDC}$ solution was then placed on the surface, followed immediately by $5 \mu \mathrm{L}$ of $100 \mathrm{mg} \mathrm{mL}-1$ NHS solution. These solutions were allowed to interact with the electrode with 3,3'-dithiodipropionic acid modification for $30 \mathrm{~min}$ in a $100 \%$ humidity environment to prevent solution evaporation. The surface was then rinsed with water and immersed in an aqueous $0.2 \mathrm{mg} \mathrm{mL}-1$ avidin solution for at least $120 \mathrm{~min}$, after which the surface was rinsed again. The electrode was then exposed to a $1 \mathrm{mM} 2$-aminoethanol

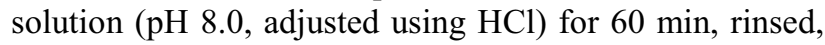
and used in hybridization detection.

\section{Results and discussion}

\subsection{Optimization of testing conditions}

Many experimental parameters, such as hybridization temperature, hybridization time, and $\mathrm{Mg}^{2+}$ ion strength, capture time, can affect the detection sensitivity of the 
assay. A series of optimizations of these parameters were carried out to improve the sensitivity and selectivity of the DNA assay. Figure 3 shows the effect of the capture time on the signal of DNA detection.

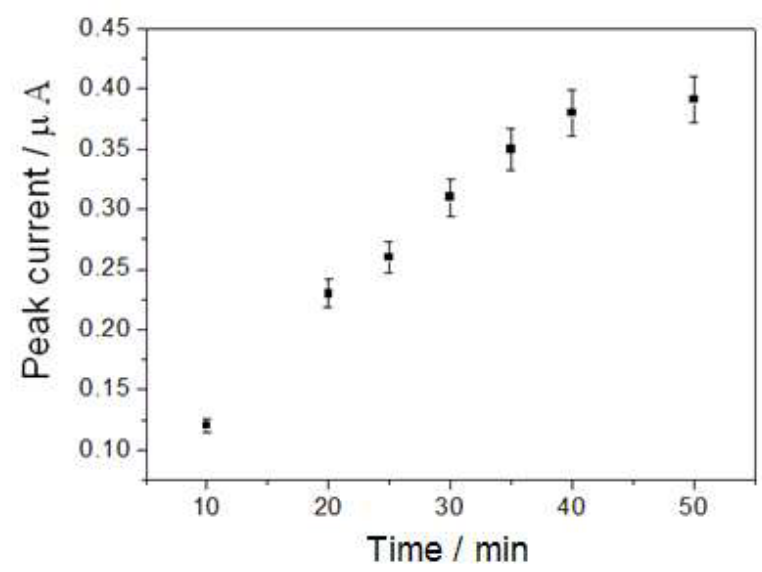

Figure 3. The DPV responds to $1.2 \times 10^{-11} \mathrm{M}$ target DNA detection with different capture time.

In this study, a $1.2 \times 10^{-11} \mathrm{M}$ complementary DNA target was incubated with DFNP for $30 \mathrm{~min}$ at a series of temperatures ranging from 25 to $45^{\circ} \mathrm{C}$. The highest signal is obtained at $37^{\circ} \mathrm{C}$. Therefore, a hybridization temperature of $37{ }^{\circ} \mathrm{C}$ was selected in the following experiments. The effect of the hybridization time has also been investigated. The target DNA was incubated with DFNP at $37{ }^{\circ} \mathrm{C}$ for different times from 10 to $50 \mathrm{~min}$. The signal responses of the assay to the different hybridization times are shown in Supporting Information Figure S6. It can be seen from this figure that the signal increases rapidly when the hybridization time increases from 10 to $30 \mathrm{~min}$ and then increases slightly from 30 to $50 \mathrm{~min}$, indicating that the hybridization reaches equilibriumat $30 \mathrm{~min}$. As a result, a reaction time of $30 \mathrm{~min}$ was selected for the DNA hybridization.

The cation $\mathrm{Mg}^{2+}$ plays an important role in DNA hybridization. For a hairpin DNA probe-based DNA assay, there is hybridization competition between intramolecular stem part hybridization and intermolecular target DNA-probe hybridization. Therefore, $\mathrm{Mg}^{2+}$ concentration in the hybridization buffer should be balanced. Although a high concentration of $\mathrm{Mg}^{2+}$ can enhance target DNA hybridized to the loop of the structure, it may also strengthen the binding of the stem part of the probe, which may adversely affect the performance of the assay. The effect of $\mathrm{Mg}^{2+}$ concentration in the hybridization buffer on the response signal of the assay. The assay produces the highest signal when the $\mathrm{Mg}^{2+}$ concentration is $2 \mathrm{mM}$. Accordingly, a $2 \mathrm{mM} \mathrm{\textrm {Mg } ^ { 2 + }}$ concentration was used throughout the experiments to obtain the highest signal.

\subsection{Principle of DNA detection}

We employed a stem-loop DNA probe dually labeled with HS and biotin at the $5^{\prime}$ - and the $3^{\prime}$ - end, respectively, which could be facilely immobilized at $\mathrm{Cds}$ nanoparticle surfaces via the Cds-S bridge and hybridized with target DNA. The signal DNA with $\mathrm{HS}$ at $5^{\prime}$ end, which could provided electrochemical signal. Two kinds of DNA have been immobilized at Cds nanoparticle to construct DFNP.

The detection strategy is demonstrated in Figure 1. Before the hybridization, the DFNP remained in the stem-loop structure, which forced the biotin to be closed to the Cds nanoparticle. Due to the steric effect of the Cds nanoparticle, the biotin was prevented from conjugating with the avidin on the electrode and resulting in that the DFNP could not be captured by the electrode. After hybridized with the target DNA, the DFNP's loop-stem structure opened and then the biotin molecule was easily bound to avidin modified electrode and resulting in that the DFNP could be captured by the electrode and the capture efficiency was proportion with the concentration of the target DNA. The target hybridization event can be sensitively transduced via detecting the electrochemical reduction current signal of MB at the DFNP.

Indeed, in stem-loop state we only found a relatively small and stable background current (Figure 2 curve a). As we challenged the sensor with $1.1 \times 10^{-11} \mathrm{M}$ target DNA, which was expected to open the stem-loop, a large signal (Figure 4 curve b) was observed. We found that as the concentration of the complementary target DNA sequence continuously increased, which was logarithmically related to the target protein concentration from $8.3 \times 10^{-12}$ to $8.3 \times 10^{-9} \mathrm{M}$. The equation for the resulting calibration plot was calculated as $y=0.139 \log x+0.163 \quad(x$ is the concentration of target DNA divided by $\mathrm{pM}$, $\mathrm{y}$ is the DPV peak current value) with correlation coefficient of 0.9923 and detection limit of $6.2 \times 10^{-12} \mathrm{M}(>3 \mathrm{SD})$. This sensitivity reflected the high signal amplification of this method and the improved signal gain as a signal-on sensor used MB as indicators.

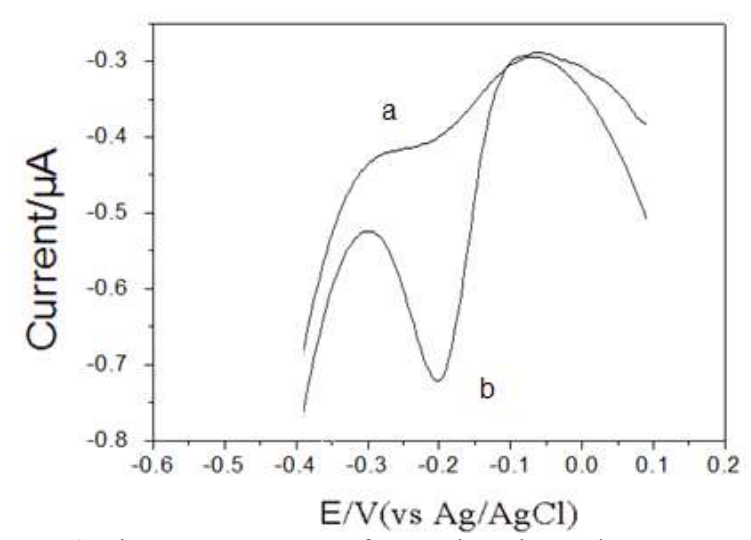

Figure 4. The DPV response of MB when the probe was incubated in phosphate buffer (a) and target DNA (b).

\section{Conclusions}

In summary, we completed a electrochemical DNA sensing strategy, which allowed the hybridization between DNA probe and target DNA occur in homogeneous solution. This assay protocol is simple, convenient and cost-effective by using this novel method, we could conveniently detect as few as $6.2 \times 10^{-12} \mathrm{M}$ target DNA. We propose that it might be a promising approach to perform DNA-based diagnostics where resources are limited, such as small clinics in developing countries or field detection. 


\section{Acknowledgements}

This work was kindly supported by the JiangXi Science and Education Committee (Grant No. GJJ14610, GJJ14620), JiangXi University of Traditional Chinese Medicine Foundation (Grant No.JZYC14A08). JiangXi Graduate student Foundation (YC2014-S287, YC2014-S295).

\section{References}

1. K. Polyak, Y. Xia, J. L.Zweier, K.W. Kinzler and B. Vogelstein: Nature Vol. 300-305 (1997), p. 389

2. G. I. Evan, K. H. Vousden: Nature Vol. 342-348 (2001), p. 411

3. D. P. Guimaraes, P. Haincdst: Biochimie Vol. 83-93 (2002), p. 84
4. K. H.Vousden, X. Lu: Nat. Rev. Cancer Vol. 594-604 (2002), p. 2

5. J. Wang, G. Rivas, X.H. Cai, M. Chicharro, C. Parrado, N. Dontha, A. Begleiter,M. Mowat, E. Palecek and P. E. Nielsen: Anal. Chim. Acta Vol. 111-118 (1997), p. 344,

6. D.E.J. Koshland: Science Vol. 1953 (1993), p. 262

7. J. Wang, D. Xu, A. N. Kawde, R. Polsky: Anal. Chem. Vol. 5576-5581 (2001), p. 73

8. H.Cai,; X. N.Cao, Y.Jiang, P. G.He, Y. Z. Fang:Anal. Bioanal. Chem. Vol. 287-293 (2003) p.375

9. F. Jelen, B. Yosypchuk, A. Kourilova, L. Novotny, E. Palecek: Anal. Chem. Vol. 4788-4792 (2002) p.74

10. J. Wang, A. N. Kawde, A. Erdem, M. A. Salazar: Analyst Vol. 2020-2025 (2001) p.126. 